\title{
Systemic Histopathology of Infant Rats Exposed to Busulfan
}

\author{
Toko Ohira $^{1 *}$, Tsubasa Saito ${ }^{1}$, Ryo Ando ${ }^{1}$, Kazutoshi Tamura ${ }^{1}$, and Toru Hoshiya ${ }^{1}$ \\ ${ }^{1}$ Pathology Division, Gotemba Laboratories, BoZo Research Center Inc., 1284 Kamado, Gotemba, Shizuoka 412-0039, Japan
}

\begin{abstract}
Busulfan is an antineoplastic bifunctional alkylating agent. We previously reported the busulfan-induced systemic histopathological changes in fetal rats and the sequence of brain lesions in fetal and infant rats. In the present study, in order to clarify the nature and sequence of busulfan-induced systemic histopathological changes in infant rats, 6-day-old male infant rats were subcutaneously administered $20 \mathrm{mg} / \mathrm{kg}$ of busulfan and histopathologically examined at 1,2, 4, 7 and 14 days after treatment (DAT). As a result, histopathological changes characterized by pyknosis of component cells were observed in the heart, lungs, stomach, intestines, liver, kidneys, testes, epididymides, hematopoietic and lymphoid tissues, dorsal skin and femur as well as in the brain and eyes (data not shown in this paper). Such pyknosis transiently appeared until 7 DAT with prominence at 2 and/or 4 DAT in each tissue, except for the thymus, in which pyknosis peaked at 1 DAT. Most of the pyknotic nuclei were immunohistochemically positive for cleaved caspase-3, indicating that pyknotic cells were apoptotic. Different from the reports of fetal and adult rats, apoptosis was also found in cardiomyocytes and osteoblasts in infant rats. (DOI: 10.1293/tox.2013-0043; J Toxicol Pathol 2014; 27: 25-29)
\end{abstract}

Key words: busulfan, systemic histopathology, apoptosis, infant rat

\section{Introduction}

Busulfan, a bifunctional alkylating agent, has been used for the treatment of chronic myeloid leukemia and for myeloablative-conditioning regimens before stem cell transplantation. In children, there are several reports of diverse effects of busulfan treatment such as pulmonary fibrosis and acute clinical neurotoxicity (spasm) ${ }^{1-3}$.

Busulfan has teratogenic and cytotoxic potentials ${ }^{4}$, and it is reported that rat fetuses exposed to busulfan developed microencephaly and microphthalmia ${ }^{5}$. Our previous studies clarified the systemic histopathological changes ${ }^{6}$ and the sequence of the central nervous system (CNS) lesions characterized by neural progenitor cell apoptosis ${ }^{7}$ in rat fetuses transplacentally exposed to busulfan on gestation day 13 . It is also reported that busulfan induces histopathological changes in the lungs ${ }^{8-11}$ in adult humans and in gastrointestinal tissues ${ }^{12}$, lymphoid tissues ${ }^{13}$ and gonadal tissues ${ }^{14-18}$ in adult rats. On the other hand, there are few reports of systemic histopathological changes in infant animals induced by busulfan except for our previous report of busulfan-induced CNS lesions in infant rats ${ }^{19}$.

In the present study, we examined the busulfan-induced systemic histopathological changes in infant rats mainly

Received: 2 August 2013, Accepted: 16 September 2013

*Corresponding author: T Ohira (e-mail: ohira-toko@bozo.co.jp) (C2014 The Japanese Society of Toxicologic Pathology

This is an open-access article distributed under the terms of the Creative Commons Attribution Non-Commercial No Derivatives (by-ncnd) License $<$ http://creativecommons.org/licenses/by-nc-nd/3.0/> .

Published online in J-stage: 6 January 2014 from the viewpoints of the distribution and sequence of pyknosis of component cells, except for brain ${ }^{19}$ and eye lesions, which will be described elsewhere in the near future.

\section{Materials and Methods}

Animals

Male newborn rats were obtained in our laboratory by mating females with males of the same colony of specific pathogen-free rats of the Sprague-Dawley strain purchased from Charles River Laboratories Japan, Inc. (Kanagawa, Japan). One foster mother with 8 male newborns were housed together in plastic Econ cages (W $340 \mathrm{~mm} \times \mathrm{D} 450 \mathrm{~mm} \times \mathrm{H}$ $185 \mathrm{~mm}$ ) with bedding (White flakes: Charles River Laboratories Japan, Inc.) in an environmentally controlled animal room (temperature, $23 \pm 3^{\circ} \mathrm{C}$; relative humidity, $50 \pm 20 \%$; air ventilation rate, 10-15 times per hour; lighting, $12 \mathrm{~h} / 12$ $\mathrm{h}$ light/dark cycle) and fed an irradiation-sterilized pelleted diet (NMF, Oriental Yeast Co., Ltd., Tokyo, Japan) and tap water ad libitum. Finally, a total of fifty 6 -day-old male rats were subjected to the experiment. The protocol of this study was reviewed and approved by the Animal Care and Use Committee of BoZo Research Center.

\section{Experimental designs}

Busulfan was obtained from Sigma Chemicals (St. Louis, MO, USA) and was suspended with olive oil.

Fifty 6-day-old male rats were equally divided into the control and busulfan groups. The animals of the busulfan group were subcutaneously administered $20 \mathrm{mg} / \mathrm{kg}(10 \mathrm{~mL} /$ $\mathrm{kg}$ body weight) of busulfan, and those of the control group 
were subcutaneously administered $10 \mathrm{~mL} / \mathrm{kg}$ of olive oil, respectively. The dose of busulfan was decided based on the results of our preliminary study. Five animals each of the busulfan and control groups were euthanized at 1, 2, 4, 7 and 14 days after treatment (DAT), respectively. At necropsy, all organs and tissues were collected from each animal for histopathological examination.

\section{Histopathology and immunohistochemistry for cleaved caspase-3}

Collected organs and tissues were fixed with $10 \%$ neutral buffered formalin. After fixation, the femur was decalcified in formic acid solution. Four- $\mu$ m paraffin sections were stained with hematoxylin and eosin (HE) and subjected to histopathological examination.

Some of the paraffin sections were also subjected to immunohistochemical examination for cleaved caspase-3. In brief, sections were reacted with rabbit anti-cleaved caspase-3 polyclonal antibody (1:200, Cell Signaling Technology, Beverly, MA, USA) at $4^{\circ} \mathrm{C}$ overnight after pretreatment. Then, the sections were reacted with an EnVision+kit (Dako Japan) at room temperature for $40 \mathrm{~min}$. These sections were visualized by peroxidase-diaminobenzidine (DAB, Dojindo Laboratories, Kumamoto, Japan) reaction and then counterstained with hematoxylin.

Histopathological examination was performed on tissues such as the heart, lungs, stomach, intestines, liver, pancreas, kidneys, testes, epididymides, thymus, spleen, mesenteric lymph node, bone marrow, skin (dorsal) and bone (femur) based on the results of our preliminary study.

\section{Results}

No deaths occurred in any group until 7 DAT. Thereafter, one animal died with severe myelosuppression at 13 DAT in the busulfan group.

In the control group, there were no histopathological changes observed in any tissues. On the other hand, in the busulfan group, histopathological changes mainly characterized by pyknosis of component cells were observed in many tissues as listed in Table 1. Histopathological changes other than pyknosis are shown in Table 2. Histopathological changes were also detected in the brain and eyes, but their data were excluded from the present paper as mentioned above.

In the cardiopulmonary system, pyknosis was observed in a small number of cardiomyocytes (Fig. 1a) and alveolar and terminal bronchiolar epithelial cells at 2 and 4 DAT (Fig. 1b). In the digestive system, pyknosis was found in a small number of hematopoietic cells in the liver at 2 DAT, glandular epithelial cells in the stomach (Fig. 1c) from 1 to 7 DAT, and crypt epithelial cells in the intestines from 1 to 4 DAT. Hematopoietic cells in the liver mildly decreased from 4 to 14 DAT, and glandular epithelial cells in the stomach showed vacuolation at 4 DAT.

In the urogenital system, pyknosis was found in a small number of proximal and distal tubule epithelial cells in the kidneys (Fig. 1d) at 2 and 4 DAT. Pyknotic changes in spermatogonia started at $1 \mathrm{DAT}$ and became moderate at 2 and 4 DAT in the testes (Fig. 1e). Thereafter, seminiferous tubules showed atrophy with depletion of germ cells at 7 and 14 DAT, at which point only Sertoli cells were left in the germinal epithelium of markedly atrophied seminiferous tubules (Fig. 1f). Pyknosis was also found in a small number of epithelial cells in the epididymides from 2 to 7 DAT.

In the hematopoietic and lymphoid system, the thymus showed moderate cortical atrophy at 2 and 4 DAT following moderate or mild pyknotic changes in cortical lymphocytes at 1 and 2 DAT (Fig. 1g). Similar but less severe changes were observed in mesenteric lymph nodes at 4 and 7 DAT. In the spleen, a minimal or mild decrease in the number of hematopoietic cells was detected from 2 to 14 DAT. In the bone marrow, mild or moderate pyknotic changes of hematopoietic cells were found from 1 to 7 DAT. A decrease in the number of hematopoietic cells with fat cell infiltration started at 2 DAT, progressed thereafter and became prominent at 14 DAT (Fig. 1h). In the other tissues, pyknosis was found in a small number of hair follicle epithelial cells (Fig. 1i) in the dorsal skin and osteoblasts (Fig. 1j) in the femur at 2 and 4 DAT. Most of the pyknotic nuclei were immunohistochemically positive for cleaved caspase-3 (Fig. 1e, inset), indicating that pyknotic cells were apoptotic.

\section{Discussion}

In the present study, we examined the nature and sequence of systemic histopathological changes observed in infant rats exposed to busulfan $(20 \mathrm{mg} / \mathrm{kg})$ at 6 days of age. As mentioned above, those in the CNS have been previously reported $^{19}$, and those in the eyes will be published elsewhere in the near future.

Pyknosis of component cells was detected in many tissues (Table 1). Among them, the thymus was moderately affected by pyknosis at 1 DAT, and the bone marrow and testes were moderately affected by pyknosis at 2 and 4 DAT. Most of the pyknotic nuclei were immunohistochemically positive for cleaved caspase-3. This strongly indicates that pyknotic cells are apoptotic. In addition, moderate cortical atrophy was observed simultaneously with moderate pyknosis of cortical lymphocytes in the thymus, a moderate to marked decrease in the number of hematopoietic cells with infiltration of fat cells was found from 4 to 14 DAT in the bone marrow, and moderate or marked atrophy due to depletion of germ cells developed at 7 and 14 DAT in the testes. Thus, histopathological changes remained until 14 DAT in the bone marrow and testes, and whether or not the rats could recover from such lesions in the bone marrow and testes thereafter was not clear in the present study. On the other hand, histopathological changes observed in tissues other than the bone marrow and testes were considered to be transient in nature.

Although there were no reports of cardiac lesions in fetal $^{6}$ or adult rats ${ }^{12}$ following exposure to busulfan, apoptosis of cardiomyocytes was detected in infant rats in the pres- 
Table 1. Distribution and Sequence of Pyknotic Cells in Rat Infant Tissues Exposed to Busulfan

\begin{tabular}{|c|c|c|c|c|c|c|c|c|c|c|}
\hline \multirow{3}{*}{$\begin{array}{r}\text { Dose of busulfan } \\
\text { Days after treatment } \\
\text { No. of animals examined }\end{array}$} & \multicolumn{5}{|c|}{$0 \mathrm{mg} / \mathrm{kg}$} & \multicolumn{5}{|c|}{$20 \mathrm{mg} / \mathrm{kg}$} \\
\hline & 1 & 2 & 4 & 7 & 14 & 1 & 2 & 4 & 7 & 14 \\
\hline & 5 & 5 & 5 & 5 & 5 & 5 & 5 & 5 & 5 & 4 \\
\hline \multicolumn{11}{|l|}{ Heart } \\
\hline Cardiomyocytes & - & - & - & - & - & - & \pm & \pm & - & - \\
\hline \multicolumn{11}{|l|}{ Lungs } \\
\hline Epithelial cells of alveoli or terminal bronchioles & - & - & - & - & - & - & \pm & \pm & - & - \\
\hline \multicolumn{11}{|l|}{ Stomach } \\
\hline Glandular epithelial cells & - & - & - & - & - & \pm & + & + & \pm & - \\
\hline \multicolumn{11}{|l|}{ Intestines } \\
\hline Crypt cells & - & - & - & - & - & \pm & \pm & \pm & - & - \\
\hline \multicolumn{11}{|l|}{ Liver } \\
\hline Hematopoietic cells & - & - & - & - & - & - & \pm & - & - & - \\
\hline \multicolumn{11}{|l|}{ Kidneys } \\
\hline Tubular cells & - & - & - & - & - & - & \pm & \pm & - & - \\
\hline \multicolumn{11}{|l|}{ Testes } \\
\hline Spermatogonia & - & - & - & - & - & \pm & ++ & ++ & \pm & - \\
\hline \multicolumn{11}{|l|}{ Epididymides } \\
\hline Epithelial cells & - & - & - & - & - & - & + & + & \pm & - \\
\hline \multicolumn{11}{|l|}{ Thymus } \\
\hline Lymphocytes of the cortex & - & - & - & - & - & ++ & + & - & - & - \\
\hline \multicolumn{11}{|l|}{ Mesenteric lymph node } \\
\hline Lymphocytes of the cortex & - & - & - & - & - & - & - & + & - & - \\
\hline \multicolumn{11}{|l|}{ Bone marrow } \\
\hline Hematopoietic cells & - & - & - & - & - & + & ++ & ++ & + & - \\
\hline \multicolumn{11}{|l|}{ Skin (dorsal) } \\
\hline Epithelial cells of hair follicles & - & - & - & - & - & - & \pm & \pm & - & - \\
\hline \multicolumn{11}{|l|}{ Bone (femur) } \\
\hline Osteoblasts & - & - & - & - & - & - & \pm & \pm & - & - \\
\hline
\end{tabular}

No. of pyknotic cells/No. of cells counted: - , almost absent; \pm , minimal $<25 \%$; +, mild $25 \%-50 \%$; ++, moderate $50 \%-75 \%$; +++, marked $>75 \%$.

Table 2. Summary of the Histopathological Findings for Rat Infant Tissues Exposed to Busulfan

\begin{tabular}{|c|c|c|c|c|c|c|c|c|c|c|}
\hline \multirow{3}{*}{$\begin{array}{r}\text { Dose of busulfan } \\
\text { Days after treatment } \\
\text { No. of animals examined }\end{array}$} & \multicolumn{5}{|c|}{$0 \mathrm{mg} / \mathrm{kg}$} & \multicolumn{5}{|c|}{$20 \mathrm{mg} / \mathrm{kg}$} \\
\hline & 1 & 2 & 4 & 7 & 14 & 1 & 2 & 4 & 7 & 14 \\
\hline & 5 & 5 & 5 & 5 & 5 & 5 & 5 & 5 & 5 & 4 \\
\hline \multicolumn{11}{|l|}{ Stomach } \\
\hline Vacuolation of glandular epithelial cells & - & - & - & - & - & - & - & + & - & - \\
\hline \multicolumn{11}{|l|}{ Liver } \\
\hline Decreased hematopoietic cells & - & - & - & - & - & - & - & + & + & + \\
\hline \multicolumn{11}{|l|}{ Testes } \\
\hline Atrophy with depletion of germ cells & - & - & - & - & - & - & - & - & ++ & +++ \\
\hline \multicolumn{11}{|l|}{ Thymus } \\
\hline Atrophy of the cortex & - & - & - & - & - & - & ++ & ++ & - & - \\
\hline \multicolumn{11}{|l|}{ Mesenteric lymph node } \\
\hline Atrophy of the cortex & - & - & - & - & - & - & - & \pm & + & - \\
\hline \multicolumn{11}{|l|}{ Spleen } \\
\hline Decreased hematopoietic cells & - & - & - & - & - & - & + & + & + & \pm \\
\hline \multicolumn{11}{|l|}{ Bone marrow } \\
\hline Decreased hematopoietic cells with fat cells infiltration & - & - & - & - & - & - & + & ++ & ++ & +++ \\
\hline
\end{tabular}

Lesion area/Tissue area observed: - , almost absent; \pm , minimal $<25 \% ;+$, mild 25\%-50\%; ++, moderate 50\%-75\%; +++, marked $>75 \%$.

ent study, suggesting a susceptibility of the infant rat heart to busulfan. Regarding pulmonary lesions, it has been reported in humans that long-term and/or high-dose busulfan therapy brought about such pulmonary lesions as bronchopulmonary dysplasia and diffuse interstitial pulmonary fibrosis in adults $^{9-11}$ and children ${ }^{1,2}$. These lesions are known as "busulfan lungs." In the lungs of fetal ${ }^{6}$ and infant rats, only transient apoptotic changes were detected in alveolar and terminal bronchiolar epithelial cells.

With regard to histopathological changes in the gastrointestinal tissues, apoptotic changes were common in fetal ${ }^{6}$ and infant rats. Namely, they were milder in the intestine than in the stomach in fetal and infant rats, while they were reported to be milder in the stomach than in the intestine 

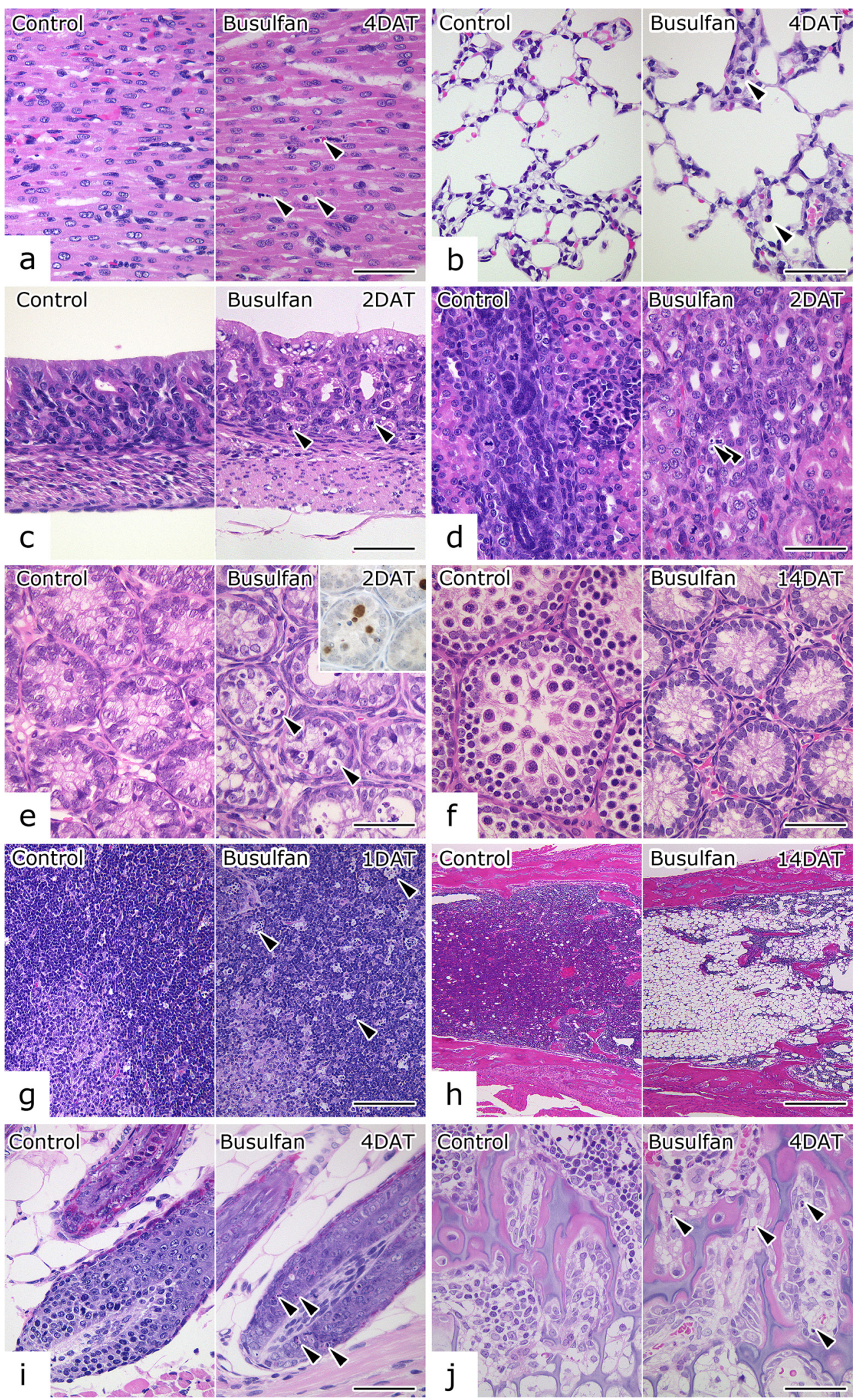

Fig. 1. Histopathological changes in infant rat tissues. In the busulfan group, pyknosis (arrowhead) was observed in cardiomyocytes (a), alveolar or bronchiolar epithelial cells (b), glandular epithelial cells in the stomach (c), uriniferous tubule epithelial cells in the kidneys (d), spermatogonia (e), lymphocytes in the thymus (g), hair follicle epithelial cells (i) and osteoblasts in the femur (j). Pyknotic nuclei were immunohistochemically positive for cleaved caspase-3 (e, inset). At 14 DAT, only Sertoli cells were left in the germinal epithelium of markedly atrophied seminiferous tubules (f), and marked depletion of hematopoietic cells with prominent infiltration of fat cells was observed in the femur bone marrow (h). HE stain, inset of (e) cleaved caspase- 3 immunostaining. (a-f, i and j) Bar=50 $\mu \mathrm{m}$. (g) Bar=100 $\mu \mathrm{m}$. (h) Bar $=500 \mu \mathrm{m}$. 
in adult rats ${ }^{12}$. In humans ${ }^{8}$, although there were no reports of histopathological changes in the gastrointestinal tissues, clinical signs of nonspecific gastroenteritis were reported. In the kidneys, although there were no reports of apoptosis in tubular epithelial cells in adult rats and humans, apoptosis of tubular epithelial cells was observed in fetal ${ }^{6}$ and infantile rats, suggesting that tubular epithelial cells of infant rats still remain susceptible to busulfan. The outline of the testicular lesions in infant rats was similar to those in adult rats $^{14-18}$, while there have been no reports of testicular lesions in humans.

Histopathological changes in the thymus and mesenteric lymph nodes were similar between infant and adult rats $^{12,13}$. On the other hand, atrophy of the splenic white pulp, reported in adult rats ${ }^{13}$, was not clear in infant rats. In the bone marrow of infant rats, as mentioned above, the number of hematopoietic cells decreased with time and became marked at 14 DAT with prominent infiltration of fat cells. This corresponded well to depressed bone marrow cellularity reported in adult rats ${ }^{12,13,20}$.

In our previous study on histopathological changes in fetal rats ${ }^{6}$, we observed apoptosis of component cells in mesenchymal tissues such as craniofacial tissues, the mandible, limb buds and the tail bud. In the present study on histopathological changes in infant rats, apoptosis was found in hair follicle epithelial cells in the dorsal skin and osteoblasts in the femur, which were not reported in adult rats.

In conclusion, the present study showed that busulfaninduced histopathological changes were characterized by apoptosis of component cells and that the distribution and sequence of apoptosis showed some differences, especially between infant and adult rats, probably reflecting the difference in susceptibility of component cells to busulfan between them.

Acknowledgements: The authors gratefully acknowledge Dr. Kunio Doi, Professor Emeritus of the University of Tokyo, for critical review of the manuscript, and Mr. Pete Aughton, D.A.B.T., ITR Laboratory Canada Inc., for language editing of this paper.

\section{References}

1. Oakhill A, Green ID, Knowlson GT, Cameron AH, Shah KJ, Hill FGH, and Mann JR. Busulphan lung in childhood. J Clin Pathol. 34: 495-500. 1981. [Medline] [CrossRef]

2. Fauroux B, Clement A, and Toumier G. Pulmonary toxicity of drugs and thoracic irradiation in children. Rev Mal Respir. 13: 235-242. 1996. [Medline]

3. Vassal G, Deroussent A, Hartmann O, Challine D, Benhamou E, Valteau-Couanet D, Brugieres L, Kalifa C, Gouyette A, and Lemerle J. Dose-dependent neurotoxicity of highdose busulfan in children: A clinical and pharmacological study. Cancer Res. 50: 6203-6207. 1990. [Medline]

4. Bishop JB, and Wassom JS. Toxicological review of bu- sulfan (Myleran). Mutat Res. 168: 15-45. 1986. [Medline] [CrossRef]

5. Furukawa S, Usuda K, Abe M, and Ogawa I. Microencephaly and microphthalmia in rat fetuses by busulfan. Histol Histopathol. 22: 389-397. 2007. [Medline]

6. Ohira T, Ando R, Andoh R, Nakazawa T, Nishihara K, Yamamoto S, Nakamura N, and Tamura K. Distribution and sequence of pyknotic cell in rat fetuses exposed to busulfan. J Toxicol Pathol. 22: 167-171. 2009. [Medline] [CrossRef]

7. Ohira T, Ando R, Okada Y, Suzuki H, Saito T, Nakazawa T, Nishihara K, Yamamoto S, Nakamura N, and Tamura K. Sequence of busulfan-induced neural progenitor cell damage in the fetal rat brain. Exp Toxicol Pathol. 65: 523-530. 2013. [Medline] [CrossRef]

8. Gureli N, Denham SW, and Root SW. Cytologic dysplasia related to Busulfan (Myleran) therapy. Obstet Gynecol. 21: 466-470. 1963. [Medline]

9. Littler WA, Kay JM, and Hasleton PS. Busulfan lung. Thorax. 24: 639-655. 1969. [Medline] [CrossRef]

10. Burns WA, MacFarland W, and Matthews MJ. Busulfaninduced pulmonary disease: report of a case and review of the literature. Am Rev Respir Dis. 101: 408-413. 1970. [Medline]

11. Buggia I, Locatelli F, Regazzi MB, and Zecca M. Busulfan. Ann Pharmacother. 28: 1055-1062. 1994. [Medline]

12. Sternberg SS, Philips FS, and Scholler J. Pharmacological and pathological effects of alkylating agents. Ann N Y Acad Sci. 68: 811-825. 1958. [Medline] [CrossRef]

13. Tange T. Significance of the bone marrow lymphocyte hematopoietic regeneration following acute injury due to cobalt-60 irradiation and cytotoxic drugs. Acta Pathol Jpn. 24: 93-117. 1974. [Medline]

14. Kasuga F, and Takahashi M. The endocrine function of rat gonads with reduced number of germ cells following busulphan treatment. Endocrinol Jpn. 33: 105-115. 1986. [Medline] [CrossRef]

15. Udagawa K, Ogawa T, Watanabe T, Yumura Y, Takeda M, and Hosaka M. GnRH analog, leuprorelin acetate, promotes regeneration of rat spermatogenesis after severe chemical damage. Int J Urol. 8: 615-622. 2001. [Medline] [CrossRef]

16. Horn MM, Paz AH, Duarte ME, Baldo G, Belardinelli MC, Matte U, Lima EO, and Passos EP. Germinative testicular cells and bone marrow mononuclear cells transplanted to a rat model of testicular degeneration. Cloning Stem Cells. 10: 543-546. 2008. [Medline] [CrossRef]

17. Hodel C, Ettlin RA, and Zschauer A. Morphological changes produced in rat testis by anticancer drugs. Arch Toxicol Suppl. 7: 147-150. 1984. [Medline] [CrossRef]

18. Linder RE, Strader LF, Slott VL, and Suarez JD. Endpoints of spermatotoxicity in the rat after short duration exposures to fourteen reproductive toxicants. Reprod Toxicol. 6: 491505. 1992. [Medline] [CrossRef]

19. Ohira T, Ando R, Saito T, Yahata M, Oshima Y, and Tamura $\mathrm{K}$. Busulfan-induced pathological changes of the cerebellar development in infant rats. Exp Toxicol Pathol. 65: 789797. 2013. [Medline] [CrossRef]

20. Dunjic A, and Cuvelier AM. Survival of rat bone marrow cells after treatment with myleran and endoxan. Exp Hematol. 1: 11-21. 1973. [Medline] 